\title{
European Duties of Social Justice: A Kantian Framework ${ }^{*}$
}

\author{
R.J.G. (RUTGER) CLAASSEN (iD \\ Utrecht University, Utrecht
}

\begin{abstract}
This contribution asks how to approach the question of whether the European Union should replacing or supplementing member states - also be a locus of social justice-based duties to provide welfare state services. The contribution scrutinizes two important theories of global justice (cosmopolitan and relational theories) and finds that their normative assumptions hinder them from adequately addressing this question. A new theory is proposed, inspired by Immanuel Kant's political philosophy. The core idea is that social justice requires public authorities to protect citizens against private forms of coercion; and that the level (national, European, global) at which such authority needs to be exercised depends on which arrangement best protects citizens' rights to independence. The paper outlines several duties of global justice to give specificity to this general principle, and then applies them to the case of integrating European welfare states.
\end{abstract}

Keywords: social justice; Immanuel Kant; welfare state; European Union; autonomy

\section{Introduction}

Both in political discourse and in political philosophy, it has long been taken for granted that the nation-state is the appropriate political community within which citizens owe each other duties of justice. Globalization has called into question this automatism of identifying the relevant political community with the nation-state, and cosmopolitans have argued that we should recognize duties of justice on a global scale and where possible strive for a world community realizing global justice. For those living on the European continent, however, there is the intermediate question of whether the European Union is an appropriate political unit to allocate duties of justice (either supplementing or replacing member states). This is the normative question of social justice in Europe behind political debates about a more 'Social Europe'.

Here I restrict social justice to citizens' entitlements to those goods, services and forms of regulation generally associated with the welfare state, such as access to health care and education, labour market regulation, social insurance against risks such as unemployment and old age, and income protection. These domains reflect the core of welfare state services built up in many European states. There is a variety of types of welfare states which provide different emphases (Esping-Andersen, 1990), but I assume social justice relates to some common denominator within this variety. At stake in the debate over Social Europe is the question of whether welfare state services should - in the name of social justice - be provided on a national or a European scale, against the background of an intensified

\footnotetext{
*I am grateful to all the participants in the workshops leading up to the preparation of this Special Issue, especially Mathieu Segers, Juri Viehoff and Andrea Sangiovanni for their questions, comments and suggestions. I also want to thank Jos Philips and Sem de Maagt for their extensive written feedback. Finally, I thank the two anonymous referees of this journal for their valuable comments which have definitely greatly improved this contribution.
} 
economic liberalization of global and European markets which puts pressure on national welfare state arrangements.

To make a contribution, I first need to survey existing theories of global justice, which have been the subject of much philosophical theorizing. Given the structural similarities (both deal with nation-state-transcending duties of justice) one expects some guidance from this for the specific European context as well. ${ }^{1}$ I first assess cosmopolitan and relational theories of global justice and their application to the European question (section I). This paves the way for my own Kantian-inspired approach. It starts off from the idea that the legitimation of public authority centres on the protection of the conditions for citizens' right to independence. Whether these conditions can best be protected at the nation-state or European level, requires a 'calculus of right' to be executed from the perspective of already existing states. This leads to three duties of global justice: a duty not to coerce other states into global integration, a duty to integrate conditional on the calculus, and a set of duties between independent states (section II). The latter set in turn consists of three duties: a duty not to exploit other states in co-operative relations, a duty not to impose wrongful harm on other states, and a duty of assistance (section III). This theory is then applied to the question of Europe, where I argue that from the point of view of social justice, states are free to push or not to push for full integration of welfare state services between them. On the other hand, they do have a duty not to exploit other European states' welfare systems and a duty to assist poorer states to promote economic convergence (section IV).

\section{Cosmopolitan and Relational Approaches}

In the global justice debate one key distinction is between non-relational and relational theories, which defend different starting points about what ground triggers duties of justice (Armstrong, 2012). Non-relational theorists argue that all human beings owe duties of justice to others on behalf of their common humanity, while relational theorists argue that human beings owe duties of justice to those with whom they stand in some special relationship. Another distinction is about scope; for instance, between statists (accepting only nation-state duties) and cosmopolitans (accepting global duties). Relational theorists can be statist or cosmopolitan, while non-relational theorists, given their reference to humanity as a whole, are often cosmopolitans (but see section III!). Let's briefly consider both, starting with the cosmopolitan position, grounded in a non-relational view of justice.

Cosmopolitan arguments usually start with moral cosmopolitanism: all human beings deserve equal moral concern and respect. Transposing the language of community and citizenship onto the global plane, moral cosmopolitans hold that all persons are citizens of the world community. Disregarding boundaries, human beings in a privileged position have moral duties towards others in vulnerable positions everywhere. Cosmopolitan theories differ in the substance given to these duties; from minimal human rights protection up to full equalization of resources. They also differ on the channels through which they ought to be discharged, some advocating individual level-duties (donations to NGOs for example), but many others a form of political cosmopolitanism in which nation-states are

\footnotetext{
${ }^{1}$ The philosophical literature on social justice in Europe is still in its infancy. In addition to the approaches discussed in this contribution, see Crum (2011), Viehoff (2015), Neyer (2012) and Wolthuis (2017).
} 
integrated in governance schemes which safeguard the world's most vulnerable members. The cosmopolitan argument for European integration (including Europeanization of welfare) is that it can serve as a first step to such global integration. Several authors have argued for such a position. ${ }^{2}$

A neat example is provided by Luis Cabrera, who holds that the EU is an example of an integrated supranational order, 'a system in which the dynamics of regional economic and political integration have opened spaces for the promotion of more cosmopolitan distributive outcomes, as well as for the securing of a narrow but robust package of individual rights recognized above the state' (Cabrera, 2005, p. 190). Writing before the Euro crisis (!), he argues that 'the person born into a historically very poor region of a state such as Ireland or Portugal, Spain or Greece is less handicapped by that starting point than in the past. As integration deepens, that person's children and grandchildren can expect to be more nearly equal to those in the more affluent regions of Europe in the resources and opportunities immediately available to them' (Cabrera, 2005, p. 193). Finally, Cabrera sees a potential to apply this logic of integration to other parts of the world, as increased economic co-operation gradually leads to the expansion of individual rights and schemes of redistribution. Expanding welfare states to the European level is better than keeping them on a nation-state level; but ultimately only an intermediate step on the road to what cosmopolitan morality requires politically: global integration.

This kind of argument has several problems. First, the argument is in tension with the cosmopolitan's own professed starting point. If moral concern is for the most vulnerable, then expending scarce resources on integrating medium-income countries into (even) richer welfare systems seems the wrong kind of priority. The argument that this facilitates institutional learning which can later be spread to non-European countries does not convince in the face of dire poverty elsewhere. Even accepting that constraints of feasibility currently prohibit a global welfare state but would allow forms of regionalization, one could do much today to alleviate global poverty without establishing a global welfare state. Cosmopolitanism's moral impetus makes it morally arbitrary, or even counterproductive, to stop efforts to pool welfare at the borders of the EU.

Second, one can dispute whether moral duties to combat injustices on a global or European scale justify creating a more-or-less fully-fledged common welfare state. Even accepting equality of moral consideration, duties to help always need to be tailored to the possibilities of those doing the helping. A balance needs to be struck between recipients' rights and donors' duties. One can only require someone to help if it doesn't come 'at a comparable cost to oneself' (Gewirth, 1996). In contexts of vast wealth inequalities, this sets stringent limits to the scope of common welfare state arrangements. Welfare states are risk-pooling mechanisms, sustainable at different levels of generosity, depending on the level of wealth (related to labour productivity) of the political communities in question. Imagine a world in which autarkic countries would have no contact with each other. If all countries on their own would have the wealth level of, say, Germany, there would be no need for establishing a welfare state between them. Each country could itself sustain a welfare state at German-style levels of generosity. A global welfare state would

\footnotetext{
${ }^{2}$ Widely discussed examples include Habermas (2003) in philosophy, Beck and Grande (2007) and Delanty (2005) in sociology, Manners (2008) in international relations. For a critical discussion with which my critique shares some affinities, see Kamminga (2017).
} 
be economically sustainable and politically feasible (since all populations would remain at roughly the same levels of wealth), but why would it be necessary or useful? By contrast, in a world with vastly different wealth levels, it may be necessary (morally imperative) to raise all countries to Germany's wealth level, but economically unsustainable and politically unfeasible to do so, when there are not enough Germanys, compared to the vast populations of poorer countries, and the wealth differences are too great. This logic may also apply to a European welfare state. ${ }^{3}$ To the extent that we are in such a dilemmatic situation, a supranational welfare state is either possible but unnecessary or necessary but impossible (more precisely, we face a spectrum between the two opposite situations: to the extent that a global welfare state becomes more economically feasible, it becomes less morally necessary, and vice versa). ${ }^{4}$

The argument so far does not imply rich countries would have no global/European duties of justice, just that they do not have welfare-state-like redistributive duties. This leaves unaffected duties to help countries attacking domestic sources of poverty, and duties not to harm poorer countries through the relations maintained with them. Such duties typically are the focus of the relational approach. Turning now to such relational theories, they are based on the idea that justice is triggered by relationships between people. There is a wide variety of relational positions, both in terms of their view of the grounds (what relations trigger duties, such as co-operation, coercion, dependence) and the scope of justice (some accepting strong global duties, others merely national duties). I will here focus on Andrea Sangiovanni's theory, since he has applied relationalism to the EU context.

Sangiovanni presents his 'reciprocity-based internationalism' as an alternative to cosmopolitanism and statism. Against statists, he accepts duties beyond the borders of nation-states. Against cosmopolitans, he emphasizes these duties should be differentiated, not implying the same levels of equalization globally. The rationale for differentiation is that duties of justice are triggered by co-operative relations in which there is a "mutual production of collective goods'. Different types of relations deliver different kinds of collective goods, and duties of justice differ accordingly: 'What reciprocity requires among friends, citizens and residents of states, EU citizens and residents or members of the WTO will be different not only in virtue of the diverse kinds of collective goods generated by institutions but also the way in which such goods are produced' (Sangiovanni, 2013, p. 220). ${ }^{5}$ In the EU-context, Sangiovanni argues for recognizing three distinct types of solidarity requirements. National solidarity within nation-states is the familiar core of statist theories. Beyond this, both member state solidarity and transnational solidarity require an interpretation of the point and purpose of EU collaboration. Sangiovanni argues this purpose lies in 'an attempt to support the interests of each of its member states in enhancing both growth and internal problem-solving capacity (including the capacity to act on domestic commitments to national solidarity) against a background of regional stability' (Sangiovanni, 2013, p. 228). Demands of justice arise because mutual relations also carry

\footnotetext{
${ }^{3}$ Jürgen Habermas argues for European integration as a stepping-stone for establishing peaceful relations between nationstates (Habermas, 2012; Kant, 1996a). This argument doesn't fall prey to the same tension, but, it is problematic for understanding the integration of welfare state services (unless one thinks peace between nations requires common welfare states between them). Habermas's arguments for European integration contain multiple strands. See Habermas (1998b, 1998a, 2001, 2003, 2012); for criticism Sangiovanni (2012a) and Streeck (2014).

${ }^{4}$ It should be noted, though, that the dilemma is defeasible, in several ways, depending on empirical circumstances. I come back to this in section IV.

${ }^{5}$ For a defence, see Sangiovanni (2007a, 2012b).
} 
risks, which are unevenly distributed between EU member states. Sangiovanni catalogues several risks, amongst which is downward pressure on social protection in the national sphere. Justice (as member state solidarity) requires an insurance against these risks, on the level which one would have chosen had one not known one's place in the distribution (a Dworkinian hypothetical insurance mechanism).

Sangiovanni's theory is more useful than cosmopolitanism for understanding the problem of maintaining a welfare state for European nations, which indeed arises because there already is a form of economic co-operation (the internal market) which interacts in complex ways with welfare state services realizing demands for social justice. Sangiovanni's theory also persuasively acknowledges (against statists) that demands of justice may exceed the nation-state level, without pleading (like cosmopolitans) for undifferentiated demands for equalization on a global scale. I will take over this idea, that justice requirements need to be differentiated according to the type of relation and co-operation involved. ${ }^{6}$ The main problem seems to me to be triggered by the two-step methodology of his theory: first to identify which forms of co-operation exist, then to identify which principles of justice should be taken to accompany that form. Taking current co-operative practices as a fixed point, the option to degrade/upgrade existing levels of co-operation is left untouched. Hence while reciprocity-based internationalism can criticize unbalanced packages of cooperation (some parties facing high risks of co-operation while others do not), it cannot deal with choices between existing and other possible balanced packages of co-operation. Consequently, Sangiovanni's theory leaves the choice between either perfecting the EU by creating a European welfare state or backtracking on economic co-operation in order to rebuild national welfare states outside of the domain of theorizing social justice. ${ }^{7}$

In earlier work, Sangiovanni stated that his theory is indeed less ambitious in this respect, but not in contradiction with other more ambitious theories which 'seek to outline new global orders 'beyond the state' (Sangiovanni, 2007a, p. 38). However, it is worthwhile to see if there is an alternative, which saves the above-mentioned advantages of his position, but can theorize normative requirements to start/stop co-operating across borders. Of course, a relational theory may outsource this choice to another compartment of normative theory, for example in terms of 'telic legitimacy' (see Sangiovanni's contribution to this Special Issue). My theoretical inclination is to theorize the relevant choices within the framework of social justice itself.

\section{Justice as Public Protection against Private Coercion}

In the remainder of the contribution, I provide the outlines of an alternative approach, inspired by - a certain interpretation of - Immanuel Kant's political philosophy. It makes the question on which scale to organize welfare state services dependent on justice considerations instead of the other way around (when theorists make justice either track established co-operative practices or assume only a global scale can be just). Accepting that social justice duties differ depending on the types of relation involved, we need a non-relational criterion to argue which relations to establish. How would this work on a Kantian-inspired approach?

\footnotetext{
${ }^{6}$ In its focus on duties related to co-ordination, my approach shares affinities not only with Sangiovanni, but also with Crum (2011), Ferrara (2005) and Wolthuis (2017).

${ }^{7}$ This agnosticism is a consequence of Sangiovanni's practice-dependent methodology (Sangiovanni, 2008, 2016).
} 
The first step is to introduce a notion of freedom as independence. Without a protective political community, individuals would be constantly exposed to dangers of private coercion, forms of manipulation and interference with what they would otherwise prefer to do: wives by husbands, employees by employers, believers by priests, etc. The legitimation of public coercion is to prevent such private coercion. A society is just to the extent that public authority succeeds in doing so. Justice is here related to a 'non-relational' concern, namely with a characteristic of individuals: their freedom. However, since freedom is always exercised within social practices and since its opposite, coercion by others, is also a feature of social practices, this non-relational concern is not atomistic or non-relational in the stronger sense (implicit is a relational conception of free agency itself (see Claassen, 2017, 2018). In Kant's terms, each individual has an innate right to freedom, defined as 'independence from being constrained by another's choice' (Kant, 1996b, p. 393). A rightful or just condition obtains where each individual's choices are consistent with the choices of others, that is, not hindering them (ibid., p. 387). Public coercion is necessary to prevent private coercion, in Kant's paradoxical formulation as a 'hindering of a hinderance to freedom' (ibid., p. 388) which restores the rightful condition.

A second step is to introduce Kant's view that individuals have a duty to co-operate with others to leave the state of nature and establish a rightful condition, because, since each has an innate right to freedom against others, each also has a duty to respect others' right to freedom. Since that right can only be assured in a civil state, co-operating with others to reach that state is obligatory (Kant, 1996b, pp. 456, 461). In contrast to cosmopolitanism, justice here is not a commitment of one human being vis-à-vis all global others, but a commitment of those human beings who find themselves living in the same society (a more or less territorially coherent community). These duties are owed qua fellow members in society. In contrast to relational theories, duties are not owed because we co-operate in providing collective goods (generating a surplus which in turn triggers distributive questions), but because we interact with each other in ways which have (positive or negative) effects on each person's opportunities for living an independent life. The latter observation is relational, but the emphasis is on a different aspect of human interactions, which functions as a practice-independent normative standard.

Third, Kant accepts the idea of other social contract theorists that states live in an international state of nature between them. However, he claims in his famous essay 'On Perpetual Peace' that this does not imply that states are bound by duty to give up their statehood and merge into a world republic. He says that 'they do not at all want this' (integration into a world republic), and therefore must settle for 'the negative surrogate of a league that averts war', that is some looser form of international co-operation (Kant, 1996a, p. 328). Why do states not want any further integration? And why is that a good reason, especially since Kant himself recognizes that a mere league provides a less effective guarantee against international war than a full federation? This question has spurred much debate in the Kant literature. I take my lead from Pauline Kleingeld's attractive answer. ${ }^{8}$ She emphasizes an earlier passage, where Kant points to a disanalogy between both states of nature. Whereas in the first state of nature, between individuals, there is no rightful condition at all, in the second one, between states, there already is a rightful condition (at least in those states which conform to the republican form, that is they protect their citizens against private coercion). Kant

\footnotetext{
${ }^{8}$ See also Flikschuh (2010) and Huber (2017) for similar interpretations of the Kantian position.
} 
says 'as states, they already have a rightful constitution internally and hence have outgrown the constraint of others to bring them under a more extended law-governed constitution in accordance with their concepts of right' (ibid., p. 327).

Two aspects of Kleingeld's interpretation are particularly important for my purposes. One is that a state's decision whether or not to merge with other states depends on a 'calculation of right' (my term). Kleingeld argues:

'when individuals exit the state of nature, the state they form may not be perfect. Kant believes that it is always better than the state of nature that they left behind (...). At the international level, however, the situation is quite different. When states exit the state of nature, a state of states with coercive powers is not necessarily better, in terms of right, than the international state of nature' (Kleingeld, 2004, p. 308).

Two, the calculation of right, which is in terms of individual's right to freedom, includes - in the international context - a concern for collective autonomy:

'what does explain the importance of states wanting to join (..), is Kant's view of the ideal state as the union of individuals for the purpose of being under common, self-given laws, along with his conviction that forcing states to join a state of states against their will would violate the autonomy of these individuals as well as the autonomy of the people they compose collectively.' (ibid., p. 309).

The picture that emerges is as follows. On the one hand, in Kant's theory, states cannot be forced to give up their independence and join a world republic. They are self-governing in this choice, and must guide themselves by the aforementioned calculation of right. On the other hand, Kant retains the ideal of a world republic as the only way to bring a durable peace (Kleingeld, 2004, p. 311). Moreover, Kant defends a duty of states to enter into a voluntary league, although they cannot be coerced to fulfill this duty (Kleingeld, 2004, p. 310). This is the minimal thing that can be asked of states in terms of an effort to combat the problem of establishing peace. Hence to establish a system of international cooperation is not optional for Kant, it is a duty of and between self-governing states.

This picture seems to me the most attractive way of thinking about global justice generally, including the question of European justice. A right to independence grounds the relevant duties of justice, both within and between nations. ${ }^{9}$ The position I would defend based on this discussion can be summed up as proposing three distinct duties of justice in the international context:

1. Duty not to coerce: states have a duty not to coerce other states, that is, to respect each other's collective autonomy in their choices of whether or not to integrate into international systems of governance. ${ }^{10}$

2. Duty to integrate with other states (conditional): in contemplating about whether to remain self-governing or integrate with other states (or some mix thereof), states must take

\footnotetext{
${ }^{9}$ I leave out of consideration whether Kant's concept of freedom as independence, generally considered a 'negative' concept of freedom, is sufficient. Normally a more positive concept, which includes a requirement of possessing certain personal capacities/resources, is thought to be necessary for justifying welfare state services (for example, health care and education services give people such capacities/resources). I think one can either try to show that this can be done on the basis of Kant's concept (for in order to be able to resist coercion by others, one needs these capacities/resources) or else one constructs a neo-Kantian framework based on such a positive notion of freedom.

${ }^{10}$ In the Rawlsian context, this is convincingly defended by Macedo (2004). On the relation between individual and collective autonomy, see also Habermas (1996).
} 
into account two considerations. 2a) a 'calculation of right', that is, what would be more conducive to the freedom of their citizens. To the extent that this requires further international integration of whatever scope or intensity, there is a duty to attempt to establish such international integration. I propose to see this primarily as a duty of justice between citizens within an already-formed state: they owe each other the best-possible arrangement of their freedom. 2b) However, Kant alerts us to the fact that further integration must also be seen as a duty between states to integrate further, to the extent that one or more states' not being in a rightful condition causes a threat to the peace of other countries.

3. Set of duties between independent states: whatever the level of integration reached after states have all made these decisions, there is a set of duties of global justice between states. Here we must diverge from Kant's focus on establishing peace as the motivation for co-operating in a league of nations. In the next section I focus on considering what the content of these duties might be, broadening their scope to include duties to socio-economic services. The set here introduced as the third type of duty in a Kantian framework will there be shown to itself contain three specific duties, which we need to elaborate on to get the full picture, also for the question of European integration.

From Kant we take the systematic emphasis on states' right to self-governance, the calculation of right for states, and the duty to establish international relations, all grounded in a non-relational right to individual independence. This right may require international cooperation on more fronts than Kant would have recognized in his time.

\section{A Framework of Duties between States}

In this section I present a framework of three types of global justice duties between selfgoverning states: duties not to exploit, duties not to impose harm and to assistance. First I explain the general framework, and then I discuss each of them in more detail.

The basic assumption underlying this framework is that the primary responsibility for guaranteeing individual's right to independence lies with the state of which individuals are members. To put this differently, individuals are constituted as persons, with the relevant capacities and resources guaranteeing their independence vis-à-vis each other, within the context of their state. ${ }^{11}$ Starting off from this basis, relations between states then have to deal with three types of situation. First, wherever well-constituted persons (or states representing them) interact across borders in voluntary, co-operative relations, some may wrong others. This requires redress. Second, well-constituted persons (or states representing them) who are not in a co-operative relation may nonetheless impose unsolicited wrongful harms on others across borders. This requires redress as well. Third, some states may fail in their duties to their own citizens, so that some of them are not guaranteed their right to independence; then non-well-constituted persons from these states may claim help from others across borders. Then citizens from states with well-constituted persons may face a duty of assistance.

\footnotetext{
${ }^{11}$ Some may interpret this assumption as leading to a rather libertarian view of international relations, along the lines of 'egalitarianism at home' (with mutual duties between citizens to provide each other with resources to become independent persons) and 'libertarianism abroad'. This is however not my intention. At least the duty of assistance I defend is not libertarian, and arguably the duty not to impose harm, given the substantive relations of co-operative governance this may trigger where externalities are mutual (see section IV) goes beyond what most libertarians would accept.
} 
These three international duties thus follow from the possible types of interaction between persons, given the primary duty of constituting persons lies elsewhere: 1) people may interact on a mutually voluntarily basis, or 2) on a non-voluntary basis, or 3) there may be no interaction at all. These are roughly analogous to duties between persons in civil law. People may conclude a contract with each other and this may be unjust where they exploit each other into accepting wrongful contracts. People may also impose a tort on other people, which is a harm that arises in a non-contractual setting. Finally, people may fail to honour a duty of omission; such as a duty in a case in which there were no preceding interactions between them. Below I elaborate on each of these duties. I hope to show that each of them has a distinctive moral logic (of exploitation, no-harm and help), and that together they cover at least a lot of terrain. I am however open to challenges that it carves up the moral terrain in the wrong way or that it is non-exhaustive and would need to be supplemented.

To give specificity to these duties, we need to specify a distributive principle. Elsewhere, I argued in favour of a sufficientarian distributive principle (Claassen, 2018). Citizens generally have entitlements (say, to health care, or education) up to some threshold level. The well-constituted person is the person having such a sufficient level. In contrast to widespread beliefs, the threshold need not be at a bare minimum; sufficiency can refer to generous levels of provision. Sufficientarianism only states that the structure of distribution is such as to require a threshold level (whatever it is), while above that level 'enough is enough' (against prioritarian or egalitarian distributive principles). I here must assume this principle, leave out important qualifications and complications, and ask the reader to imagine it can be defended against its rivals. Now I want to show how for each of the three duties of global justice we can apply the sufficientarian principle as well.

(i) Duties not to exploit are triggered in circumstances in which there are co-operative interactions, where two or more states co-operate in a common scheme to provide a set of mutual benefits, such as international trade relations under mutually agreed rules. When two states benefit from such trade relations, they will not necessarily benefit equally. What may be a fair distribution of the benefits (and burdens) of the surplus (compared to the baseline of not co-operating)? One state may be dominant, and able to extract much more benefits from the co-operative scheme than another, weaker state. For a sufficientarian, there is a duty not to exploit the weaker party if its citizens are at a below-threshold level. For example, citizens in country A lack adequate shelter, with wooden constructions exposed to storms and earthquakes. On a 10-point scale, if the threshold for adequate shelter is at 4, they are at level 2. Citizens in country B enjoy shelter at level 6. Suppose both countries engage in a trading scheme for construction materials. The surplus of the scheme is 3. A strictly equal distribution of the surplus would bring citizens in $\mathrm{A}$ up to $(2+1.5=) 3.5$, and citizens in $\mathrm{B}$ up to 7.5. If $\mathrm{B}$ exploits $\mathrm{A}$, A gets less. In this situation, B's duty is not to exploit, and to honour at least a strictly equal distribution of the surplus, as a recognition of both parties' status as independent states. Doing more (such as, admit a distribution of the surplus giving $2 / 3$ to $\mathrm{A}$, raising its level to 4 ) would be laudatory, but cannot be morally required. The responsibility to bring A up to the threshold level cannot be put fully on the shoulders of B. If both countries have initial levels of 6, by contrast, each can try to get as much of the surplus in the bargaining process as he can, since none of them is below-threshold. In the former case there is a 'forced bargain', given the neediness of A's citizens, in the latter case we can assume both 
countries to trade voluntarily, given their relative wealth. Hence the sufficientarian structure helps to diagnose global duties to prevent injustices as far as they arise from international co-operative interactions.

(ii) Duties not to impose harm are triggered in non-cooperative interactions. These are cases when one state imposes unwanted harms on others: negative externalities or crossborder spillovers. For example, producers in upstream country A harm the health of citizens in downstream country B by polluting a river they share. A normally has a duty to compensate for the imposition of the externality. ${ }^{12}$ Imagine A's actions set back B's citizens' health from level 6 to, say 3 (with the threshold at 4). In that case, it arguably owes compensation for bringing B's citizens to level 4, but not back to 6. Similarly, if the setback would have been from 6 to 5 (hence no subthreshold situation arises), no compensation would be due. Why? The answer is complicated, but summarizing a long analysis done elsewhere, the identification of externalities (or harms in Mill's harm principle) depends on a prior theory determining the basic interests protected by one's rights (Claassen, 2016). ${ }^{13}$ Kant's right to independence would be one way of grounding and identifying these basic interests. One stands in one's right - from the perspective of justice - to demand compensation when one suffers subthreshold-levels of the interests protected by these rights, due to the imposition of the externality (Saunders, 2011).

Together these categories describe the wanted and unwanted relations that citizens of states have with each other, and accompanying responsibilities for injustices that may arise. In the first category we find concerns - famously diagnosed by Thomas Pogge (2008) - about the imposition of a global economic order with rules biased towards richer countries' interests. The second category contains issues - climate change, cross-border crime, war, immigration - which have been the reason for many cosmopolitans to argue for global integration. Now let's introduce a third category, which we need to analytically separate from the former two, by imagining a world in which there would be no injustices of either type.

(iii) Duties to assistance are triggered by circumstances which are in themselves noninteractional, where some states have a population with below-threshold levels of poverty in one or more of its justice-relevant dimensions: life, nourishment, health, security, education etc. Imagining that we can isolate the extent to which below-threshold levels are not caused by the interactions with other countries (such that would have been absent when exploitation was avoided and all externalities compensated), is there a ground for a justice-based positive duty to assistance to alleviate remaining poverty levels? Arguably, there is. This duty is remedial, which means that it comes in to the extent that states cannot effectively manage to eradicate poverty themselves. Moreover, it is subject to demands of reciprocity. Those suffering poverty must contribute themselves as much as they are able to, suggesting forms of development aid which work towards the independence of those helped. Finally, the duty is restricted in scope to the sufficiency level for

\footnotetext{
${ }^{12} \mathrm{~A}$ more complicated situation arises when the production of the negative externality is indispensable for $\mathrm{A}$ to escape a sub-threshold situation itself, as when developing countries emit $\mathrm{CO}_{2}$ or immigrants migrate to escape poverty. Then trade-offs will have to be made.

${ }^{13}$ The categories of harm/externality are essential to understanding the moral justification of a lot of regulation along liberal lines. See chapter 1 of Arnold (2009). The issues mentioned here (such as immigration, environmental pollution) require a great deal of specific analysis about their complexities and dynamics, which cannot be captured by these concepts alone. The concepts explain only the ground: that duties of justice are triggered between states when there is an unsolicited cross-border harm imposed by one state on the other.
} 
recipients, in combination with a check on the ability to provide such a level for donors (see section I and section IV hereafter).

While this is merely an organizing framework which needs much fuller elaboration, it hopefully shows how we can think in a structured way, about the different normative ground and scope of duties of justice across state boundaries.

\section{The Question of European Social Justice}

We can now put the framework to work on the case of Europe, and the question of whether there are duties of social justice to establish welfare state-type provisions at a European level.

First, we need to interpret how European states have taken up the duty to integrate with other states so far as necessary to establish a rightful condition amongst their citizens (see end of section II). Uncontroversially, the logic of European integration has not been driven by social justice considerations relating to welfare state services. Indeed, welfare states have been taken as embedded in national cultures of provisioning, which need to be kept nationally as far as possible. Instead, European integration has mainly been driven by economic considerations (exploiting opportunities for increasing wealth by establishing an internal market), and by a host of cross-border spillover considerations: most prominently security considerations (establishing peace between former enemies), and more recently also other cross-border problems hard to solve unilaterally (immigration, environmental spillovers etc.). If states are right in their judgment that the demand to create social services for their own citizens (to guarantee their personal right to independence), considered on its own merits, does not require European-wide integrated systems of provisioning, then no duty ensues.

Such a no-duty judgment would be supported by an application to the European context of my earlier argument in the global context, that a supranational welfare state is in the current circumstances either feasible but unnecessary, or necessary but unfeasible. Redistribution of the size ending poverty cannot be a demand of justice because given the numbers of those in poverty versus the numbers in richer countries, and the productivity levels of the countries involved, this would require a sacrifice of the richer countries which would throw them into poverty themselves. This dilemmatic situation is no inescapable fact; it can be resolved in certain situations. For example, if a redistribution of wealth within richer countries would be sufficient to amass the required wealth, so that the 'global $1 \%$ ' is taxed to finance such a global welfare state, one would have found a 'hidden' taxable treasure within countries with high productivity/wealth levels, which defeats the idea that such a welfare state, where it is necessary, would not be economically feasible (it remains to be seen whether it is politically feasible to actually tax the $1 \%$ at higher levels, of course). The dilemma would also be defeated if the number of richer countries increased, so that at some point their collective wealth would be enough to support a welfare state (at their benefit levels) in - a now relatively small set of - poorer countries.

Arguably, the dilemma applies to the current European context as well. Thus, for example, Fritz Scharpf in the European context, after mentioning that GDP per capita levels between European countries differ by a factor of three to six, states: 'social transfers and public social services at a level that is considered appropriate in the Scandinavian 
countries could simply not be afforded by Greece, Spain or Portugal - let alone by the candidate countries on the threshold of eastern enlargement' (Scharpf, 2002a, p. 650). This, he judges, is a major barrier to European-wide harmonization at the level of the richest countries. Harmonization at the level of the poorest countries would be problematic for another reason: it would mean a massive impoverishment and hence be a no-go for the citizens of the richest countries. Thus, diversity in economic development precludes the possibility of establishing a European welfare state. As said above, this is not a hard law; the relative numbers could shift in the future so as to render it feasible; for the moment, though, states have probably rightly judged that the current imbalances make this infeasible.

Now one could object to this, and maintain that there is nonetheless a necessity of working (however slowly) towards the creation of a European-wide welfare state, for several reasons. Two of them I will discuss. One argument would be from European citizenship. Even if not driven by social welfare considerations, a legally enshrined form of European citizenship has now been created, in addition to national citizenship. Citizenship is generally taken to be the locus for thinking about each person's fundamental ('person-constituting') rights, including social rights (Marshall, 1950). The dual structure of citizenship now enshrined in European law would then warrant attribution of the task to guarantee such rights to both national and European levels. A duty for the EU to (also) provide services connected to social rights then is justified. To my mind, this argument is putting the cart before the horse. European integration has always been about a piecemeal transfer of powers, in functionally limited domains. The attribution of citizenship status cannot be assumed by a definitional sleight of hand to also cover the social domain, if such has not been the express interpretation of European citizenship by member states. If so, then we can very well end up with a situation in which European citizenship status is the basis for European-wide collective action in certain domains, while others remain covered by national citizenship status.

A second argument is about functional linkage. Economic co-operation induces pressures to Europeanize/globalize welfare state services as well, because it - at some level of intensity - decreases the space for nation-state policy-making. In the EU-context there is the success of negative integration in the hands of the European Court of Justice, while positive integration has lagged behind (Scharpf, 2002a, 2010). The logic behind this process was already explained by Hayek: the establishment of a free market between the units of a federal system makes it more difficult for the units to maintain their own market-restraining rules, while it becomes hard to re-establish equivalent rules at the federal level, given the heterogeneity in policy preferences between the units (Hayek, 1948). This logic would push Europe over the long run towards a federalized economic system in which the scope for high-level welfare state services is severely restricted. This situation can be appraised differently. Hayek's diagnosis of the contemporary EU has been opposed by Polanyi-inspired authors (Scharpf, 2002b; Streeck, 2011). While Hayek suggests an economic-liberal federal system is both desirable and feasible, Polanyi's analysis of the $19^{\text {th }}$-century movement towards economic liberalization and its backlash led him to predict that pushes for free markets also trigger 'countermovements' which demand social protection against the market (Polanyi, 2001). Such a countermovement can have a benign or a malicious form, ending either in the fascist uproar of the 1930s or the social-democratic regime of 'embedded liberalism' (Ruggie, 1982), with Polanyi himself 
being a strong proponent of the social-democratic countermovement. We may face a similar predicament in the EU. In the wake of the rising globalization of markets, a call for renewed protection emerges, which can either end in authoritarian nationalism or in a renewed form of embedded liberalism.

In terms of the framework of global duties, this linkage argument can be classified as a case of externalities/harm, with economic systems imposing externalities on welfare systems. If cross-boundary externalities are frequent and mutual (going more-or-less in both directions), the duty not to impose harms may have to transform into a duty to establish permanent international systems of co-operation in charge of governing the problem. ${ }^{14}$ In such situations the baseline changes from the absence of externalities to the presence of mutual externalities, and the question becomes one of dividing the surplus of the benefits of internalizing them, with as central norm the duty not to exploit others in the bargains over the surplus. Some features of the current European socio-economic context can be interpreted as violations of this duty (the trade imbalances between the Northern and Southern member states, the asymmetries in the eurozone caused by the impossibility to devalue one's currency, the asymmetric dependencies between states and their banks in negotiating debt relief measures, etc.). To the extent that such spillovers are more intense in Europe given geographical proximity on the continent, this may explain the intense nature of EU co-operation in many domains. It would lead one to acknowledge a duty to pool the capacity for welfare services if that is necessary to stop exploitation of one state by others within the European system.

In response to the linkage argument, I would like to make two points. First, while this spillover logic pushes to co-ordination of welfare state services, I remain unconvinced that a push to full integration for these services will be necessary to resolve these spillovers satisfactorily. Whether this will at some point in the future be the case, depends on empirical contingencies which are hard to foresee. In light of the Kantian right to self-governance of states, it remains important to conclude that if cross-border problems in the social domain (benefit tourism, health care tourism) can be solved by measures other than full integration, then no such duty can be established. The empirical literature shows how states are working out such lesser means in practice for the moment (Ferrara, 2005, pp. 111-166). We should also bear in mind that the forms of exploitation mentioned above (macro-economic imbalances) would require their own countermeasures, but not necessarily pooling welfare services.

Second, the force of the argument depends heavily on economic differences between member states. Attempts at exploitation, in the form of profiting from welfare services by other countries, are often driven by lower levels of economic wealth (if not extreme unemployment, such as in southern Europe). Instead of blaming the victim, this situation rather calls for measures aiming at economic convergence (similarly see Viehoff's contribution to this Special Issue). That would rather be an instantiation of the duty to assistance. Lifting the sufficientarian threshold in these countries upwards would greatly alleviate pressures on welfare states of other countries. The EU's Structural Funds can be interpreted as being motivated by such efforts at assistance. If such assistance

\footnotetext{
${ }^{14}$ The special case of mutual harms thus feeds into the Kantian duty ' $2 b$ ' mentioned in section II (integration due when states form a threat to each other), albeit expanded from peace into the socio-economic realm.
} 
measures, combined with addressing macro-economic imbalances, would work to stimulate growth leading to convergence, then pooling welfare states would be unnecessary.

Together these considerations hopefully help to understand how the Kantian-inspired framework of global justice set out here can be applied to the issue of social justice between European states. While many details need to be filled in, the framework hopefully already shows the potential to understand these issues in terms of the relevant set of duties, and to justify the cautious attitude of European states trying to maintain a certain independence in the welfare state domain while at the same time tackling cross-border spillovers into that domain arising from the economic integration they have voluntarily established for other reasons. One may not agree, and argue that the EU should (over time) work towards becoming a fully-fledged welfare state; and indeed that is certainly a permissible political move in terms of social justice; but it is not a duty, and it is important to see the reasons why.

\section{Correspondence:}

R.J.G. (Rutger) Claassen

Department of Philosophy \& Religious Studies, Utrecht University, Janskerkhof 13

3512 BL Utrecht, The Netherlands

email: r.j.g.claassen@uu.nl

\section{References}

Armstrong, C. (2012) Global Distributive Justice (Cambridge: Cambridge University Press).

Arnold, N.S. (2009) Imposing Values. An Essay on Liberalism and Regulation (Oxford: Oxford University Press).

Beck, U. and Grande, E. (2007) 'Cosmopolitanism: Europe's Way Out of Crisis'. European Journal of Social Theory, Vol. 10, No. 1, pp. 67-85.

Cabrera, L. (2005) 'The Cosmopolitan Imperative: Global Justice Through Accountable Integration'. The Journal of Ethics, Vol. 9, pp. 171-99.

Claassen, R. (2016) 'Externalities as a Basis for Regulation: A Philosophical View'. Journal of Institutional Economics, Vol. 12, No. 3, pp. 541-63.

Claassen, R. (2017) 'An Agency-Based Capability Theory of Justice'. European Journal of Philosophy, Vol. 25, No. 4, pp. 1279-304.

Claassen, R. (2018) Capabilities in a Just Society. A Theory of Navigational Agency (Cambridge: Cambridge University Press).

Crum, B. (2011) 'What Do We Owe the Poles (or the Greeks)? Three Emerging Duties of Social Justice in the European Union'. RECON Online Working Paper, Vol. 2011, No. $/ 35$.

Delanty, G. (2005) 'The Idea of a Cosmopolitan Europe: On the Cultural Significance of Europeanization'. International Review of Sociology, Vol. 15, No. 3, pp. 405-21.

Esping-Andersen, G. (1990) The Three Worlds of Welfare Capitalism (Princeton, NJ: Princeton University Press).

Ferrara, M. (2005) The Boundaries of Welfare. European Integration and the New Spatial Politics of Social Protection (Oxford: Oxford University Press).

Flikschuh, K. (2010) 'Kant's Sovereignty Dilemma: A Contemporary Analysis'. Journal of Political Philosophy, Vol. 18, No. 4, pp. 469-93.

Gewirth, A. (1996) The Community of Rights (Chicago, IL: The University of Chicago Press).

Habermas, J. (1996) Between Facts and Norms. Contributions to a Discourse Theory of Law and Democracy (Cambridge: Polity Press). 
Habermas, J. (1998a) 'Kant's Idea of Perpetual Peace: At Two Hundred Years Historical Remove'. In The Inclusion of the Other (Cambridge: Polity Press), pp. 165-201.

Habermas, J. (1998b) 'The European Nation-State: On the Past and Future of Sovereignty and Citizenship'. Public Culture, Vol. 10, No. 2, pp. 397-416.

Habermas, J. (2001) The Postnational Constellation (Cambridge, MA: The MIT Press).

Habermas, J. (2003) 'Toward a Cosmopolitan Europe'. Journal of Democracy, Vol. 14, pp. 86-100.

Habermas, J. (2012) The Crisis of the European Union. A Response (Cambridge: Polity Press).

Hayek, F. (1948) 'The Economic Conditions of Interstate Federalism'. In Individualism and Economic Order (Chicago, IL: The University of Chicago Press), pp. 255-72.

Huber, J. (2017) 'No Right to Unilaterally Claim Your Territory: On the Consistency of Kantian Statism'. Critical Review of International Social and Political Philosophy, Vol. 20, No. 6, pp. 677-96.

Kamminga, M. (2017) 'Cosmopolitan Europe? Cosmopolitan Justice against EU-Centredness'. Ethics \& Global Politics, Vol. 10, No. 1, pp. 1-18.

Kant, I. (1996a) 'Perpetual Peace'. In Gregor, M. (ed.) Practical Philosophy (The Cambridge Edition of the Worked of Immanuel Kant) (Cambridge: Cambridge University Press), pp. 317-51.

Kant, I. (1996b) 'The Metaphysics of Morals'. In Gregor, M. (ed.) Practical Philosophy (The Cambridge Edition of the Worked of Immanuel Kant) (Cambridge: Cambridge University Press).

Kleingeld, P. (2004) 'Approaching Perpetual Peace: Kant's Defence of a League of States and His Ideal of a World Federation'. European Journal of Philosophy, Vol. 12, No. 3, pp. 304-25.

Macedo, S. (2004) 'What Self-Governing Peoples Owe to One Another'. Fordham Law Review, Vol. 72, pp. 1721-38.

Manners, I. (2008) 'The Normative Ethics of the European Union'. International Affairs, Vol. 84, No. 1 , pp. $45-60$.

Marshall, T.H. (1950) 'Citizenship and Social Class'. In Citizenship and Social Class and Other Essays (Cambridge: Cambridge University Press), pp. 1-85.

Neyer, J. (2012) The Justification of Europe. A Political Theory of Supranational Integration (Oxford: Oxford University Press).

Pogge, T. (2008) World Poverty and Human Rights (Cambridge: Polity Press).

Polanyi, K. (2001) 'The Great Transformation'. In The Political and Economic Origins of Our Time (Boston, MA: Beacon Press).

Ruggie, J. (1982) 'International Regimes, Transactions, and Change: Embedded Liberalism in the Postwar Economic Order'. International Organization, Vol. 36, No. 2, pp. 379-415.

Sangiovanni, A. (2007a) 'Global Justice, Reciprocity, and the State'. Philosophy \& Public Affairs, Vol. 35, No. 1, pp. 3-39.

Sangiovanni, A. (2008) 'Justice and the Priority of Politics to Morality'. The Journal of Political Philosophy, Vol. 16, No. 2, pp. 137-64.

Sangiovanni, A. (2012a) 'Solidarity in the European Union. Problems and Prospects'. In Dickson, J. and Eleftheriadis, P. (eds) Philosophical Foundations of European Union Law (Oxford: Oxford University Press), pp. 385-411.

Sangiovanni, A. (2012b) 'The Irrelevance of Coercion, Imposition, and Framing to Distributive Justice'. Philosophy \& Public Affairs, Vol. 40, No. 2, pp. 79-110.

Sangiovanni, A. (2013) 'Solidarity in the EU'. Oxford Journal of Legal Studies, Vol. 33, No. 2, pp. 213-41.

Sangiovanni, A. (2016) 'How Practices Matter'. Journal of Political Philosophy, Vol. 24, No. 1, pp. 3-23.

Saunders, B. (2011) 'Defining the Demos'. Politics, Philosophy \& Economics, Vol. 11, No. 3, pp. 280-301. 
Scharpf, F. (2002a) 'The European Social Model: Coping with the Challenges of Diversity'. JCMS, Vol. 40, No. 4, pp. 645-70.

Scharpf, F. (2002b 2010) 'The Asymmetry of European Integration, or Why the EU Cannot Be a 'Social Market' Economy'. Socio-Economic Review, Vol. 8, pp. 211-50.

Streeck, W. (2011) 'The Crises of Democratic Capitalism'. New Left Review, Vol. 71, pp. 5-29.

Streeck, W. (2014) 'Small-State Nostalgia? The Currency Union, Germany and Europe: A Reply to Jurgen Habermas'. Constellations, Vol. 21, No. 2, pp. 213-21.

Viehoff, J. (2015) Social Justice in the European Union. A Social Democratic Ideal for an "Ever Closer Union." Oxford: DPhil Thesis at the University of Oxford.

Wolthuis, B. (2017) 'Principles of Economic Union: An Extension of John Rawls's Theory of Justice'. European Law Journal, Vol. 23, pp. 454-66. 